\title{
Cytokines in the Placenta of Pakistani Newborns With and Without Intrauterine Growth Retardation
}

\author{
SYLVIE AMU, MIRJANA HAHN-ZORIC, AISHA MALIK, RIFAT ASHRAF, SHAKILA ZAMAN, INGEMAR KJELLMER, \\ HENRIK HAGBERG, LEONID PADYUKOV, AND LARS ̊̊. HANSON
}

\begin{abstract}
Department of Clinical Immunology [S.A., MH-Z., L.P., LAH.], Gothenburg University, S-41346 Gothenburg, Sweden; Department of Obstetrics and Gynecology [S.A., A.M.], Department of Social and Preventive Pediatrics [R.A.], King Edward Medical College, 54000 Lahore, Pakistan; Department of Social and Preventive Pediatrics [S.Z.], Fatima Jinnah Medical College/Sir Ganga Ran Hospital, 54000 Lahore, Pakistan; Department of Pediatrics [I.K.], Department of Obstetrics and Gynecology [H.H.], Gothenburg University, S-41685
\end{abstract}

Gothenburg, Sweden.

\begin{abstract}
Although intrauterine growth retardation (IUGR) is a major risk factor for increased neonatal mortality and morbidity, the mechanisms behind it are not clear. We analyzed cytokine gene expression and gene polymorphisms in infants with and without IUGR in Pakistan, where IUGR is very common. 45 IUGR and 55 control mother/infant pairs were studied. mRNA for IL-10, IL-8, TNF- $\alpha$, TGF- $\beta$, IL-6, IL-4, IL- $1 \beta$, IL-12, IFN- $\gamma$ and GAPDH was quantified with RT-PCR from placenta. Cytokine and cytokine receptor gene polymorphisms for -1087IL10, -308TNFA, -174IL6, +915TGFB1, intron 2 IL1RN, +36TNFR1, 150V IL4RA and $-159 \mathrm{CD} 14$ were determined from genomic DNA. The serum levels of IL-1 $\beta$, IL-6, IL-8, IL-10, IL-12, TNF- $\alpha$ and TGF- $\beta$ were measured.

There was a significant decrease of IL-10 and IL-12, but increase of TGF- $\beta$ in the decidua and similarly decrease of IL-10, but increase of TGF- $\beta$ in the trophoblasts of the IUGR placentas compared with the non-IUGR placentas. We found significantly lower levels of IL- $1 \beta$ in serum from the mothers of the IUGR infants and of TGF- $\beta$ in serum of the infants with IUGR compared with the non-IUGR infants. We note that the IL-10 mRNA expression in the decidua was down-regulated, but the TGF- $\beta$ mRNA up-regulated in IUGR placentas of mothers from a population with multiple risk factors for IUGR. We propose that the low IL-10 in the placenta may be involved in the pathogenesis of IUGR and might possibly be treatable. (Pediatr Res 59: 254-258, 2006)
\end{abstract}

$\mathrm{I}_{\mathrm{f}}^{\mathrm{n}}$ ntrauterine growth retardation (IUGR) is a major risk factor for increased neonatal mortality, morbidity and stillbirth (1), including a considerable risk for permanent brain damage and a higher rate of failure in school (2). Found prevalence of IUGR in newborns of Lahore, Pakistan in 1984-87 was 15$16 \%$ in a rural and semi-rural population (3), in Karachi, the prevalence was $24 \%$ (4), while in a Swedish population it was $1 \%$ to $4 \%$ (5). Despite the recognized problems with IUGR and several studies on the subject, the mechanisms behind it remain unclear.

Received April 26, 2005; accepted August 22, 2005

Correspondence: Sylvie Amu, Göteborg University, Department of Clinical Immunology, Guldhedsgatan 10 A, S-413 46 Göteborg, Sweden; e-mail: sylvie.amu@ rheuma.gu.se

This study was supported by the Swedish Agency SIDA/SAREC and the Erik and Lilly Philipsson Memorial Fund.

DOI: $10.1203 / 01 . p d r .0000196332 .37565 .7 d$
When malformations and genetic causes are excluded, IUGR is characterized by placental insufficiency. An impairment in the invasion of fetal trophoblasts during implantation into the maternal decidua has been considered as a cause of insufficient remodeling of the spiral arteries into vessels of low resistance resulting in reduced utero-placental blood flow, preeclampsia and/or small for gestational age (SGA) fetuses (6). The distribution of the fetal and the maternal blood circulation in the placenta is important for efficient exchange of oxygen and nutrients and thus for the normal growth of the fetus (7).

Cytokines play a major role in reproductive events. TNF- $\alpha$ and IFN- $\gamma$ inhibit survival, growth and differentiation of trophoblast T-cells (8), while GM-CSF, CSF-1 and IL-3 appear to enhance proliferation and growth of trophoblasts $(9,10)$. IFN- $\gamma$, TNF- $\alpha$ and IL- 2 cause fetal resorbtion, whereas IL-3 and GM-CSF injected into abortion-prone mice increase fetal survival rate as well as fetal and placental weight (11).

A few studies on human pregnancy indicate that cytokines are also involved in the pathogenesis of IUGR and other pregnancy dysfunctions. There is an increased placental production of TNF- $\alpha$ in IUGR pregnancies (12) and an excess of TGF- $\beta$ during pregnancy can be associated with miscarriage (13).

In a previous investigation (14) we have showed that the levels of IL-10 mRNA were decreased and of IL-8 mRNA increased in the decidua of IUGR placentas from Swedish mothers. In the present study, we analyzed the gene expression for different Th1 and Th2 cytokines from the maternal (decidua) and the fetal (trophoblast) side of the placenta from IUGR and non-IUGR pregnancies, as well as from full-term and preterm pregnancies in a Pakistani population. We have also investigated cytokine gene polymorphisms and cytokine protein expression for certain Th1 and Th2 cytokines from

Abbreviations: IUGR, intrauterine growth retardation; GAPDH, glyceraldehide phosphate dehidrogenase; SGA, small for gestational age 
maternal and umbilical cord blood. We wanted to evaluate the possible role of these cytokines in the development of IUGR in an area where the known risk factors for IUGR such as maternal malnutrition and exposure to infections are much more frequent and complex than in Sweden. The question was whether or not the possible role of the reduced IL-10 mRNA in the decidua found in the Swedish material could be confirmed also in the Pakistani material. If that was the case, its possible role as a pathogenic mechanism behind IUGR would be strengthened and the possibility of treatment with IL-10 might be considered. In fact, we found evidence for a decreased gene expression of IL-10 in the placenta of the Pakistani mothers, supporting our previous finding in the Swedish material (14).

\section{MATERIALS AND METHODS}

Patient groups. The study group consisted of 218 pregnant women registered at the antenatal clinic of Lady Wellingdon Hospital, Lahore, Pakistan. Out of 218 mothers, 100 delivered at the hospital and the rest either delivered at home, or dropped out of the study. Only mothers who delivered at the hospital were included in the study. Placenta, whole blood and serum/cord blood samples from 45 IUGR and 55 non-IUGR mother/newborn pairs were used. Each of these two groups was further divided into a full-term and a preterm group.

All mothers had ultrasound examinations before the $20^{\text {th }}$ week of gestation. Only mothers certain of the date for the onset of pregnancy confirmed by the ultrasound examination were included in the study. Mothers with twin pregnancies, congenital anomalies diagnosed by ultrasound examination and infections diagnosed during or after deliveries, which could influence the placental configuration or expression of cytokines were excluded from the study. The IUGR was diagnosed at attended check-ups. The fundal height in $\mathrm{cm}$ was measured at each visit and plotted on a graph from $24 \mathrm{wk}$ onwards. Growth was suspected to be abnormally retarded if it was less than -2 SD. In such cases the ultrasound examination was used to help to establish the diagnosis of IUGR. The definition of IUGR was the lack of increase in estimated fetal weight ( $\leq 11 \%$ compared with standard curves, examination interval $\geq 15 \mathrm{~d}$ ) and/or pathologic Doppler velocimetry in the umbilical artery $(15,16)$. In moderate or severe cases of IUGR, Doppler test of umbilical artery blood flow velocity was used for the decision about time and mode of delivery. Placental tissues, as well as blood and serum samples, were collected by staff available $24 \mathrm{~h}$

Full-term pregnancy was defined as 37-42 completed weeks of gestation, while preterm pregnancy was less than 37 completed weeks of gestation.

Informed consent and Ethics Committeeś approval both in Pakistan (King Edward Medical College Ethics Committee) and in Sweden (The Ethics Committee of the Sahlgrenska Academy at Göteborg University) were obtained.

Collection and handling of placentas. Small tissue samples (10-100 $\mu \mathrm{g})$ were taken from the placenta immediately after delivery, both from the decidua and the trophoblast, rinsed in physiologic solution $(0.9 \% \mathrm{NaCl})$ and fixed in RNAlater (Ambion-Intermedica, Stockholm, Sweden). The placentas were handled on ice and time between the delivery of the placenta and fixation in RNAlater never exceeded $10 \mathrm{~min}$. Samples were stored at $-8^{\circ} \mathrm{C}$ at the Lady Wellingdon Hospital, brought on ice to King Edward Medical College where they were stored at $-20^{\circ} \mathrm{C}$ before shipment to Sweden on dry ice. In Sweden they were stored at $-20^{\circ} \mathrm{C}$ until analyzed.

RNA preparation. Total RNA was extracted from the fixed tissue using RNeasy Mini kit (Qiagen Inc, Valencia, CA). Isolation was done according to the manufacturer's instructions: the tissue was homogenised in a highly denaturising guanidine isothiocyanate (GITC)-containing buffer, washed with ethanol and eluted with RNase-free water. The isolate was treated with DNase Treatment \& Removal Reagents (Ambion Inc, Austin, TX) to eliminate possible remains of genomic DNA.

The yield and purity of the RNA was determined by spectrophotometric measurements of absorbances at 260 and $280 \mathrm{~nm}$ wavelengths. The quality of the RNA was checked on 1\% agarose gel with SybrGreen (BMA, Rockland, $\mathrm{ME}$ ) in the presence of a RNA standard (Human HeLa Cell Total RNA, Clontech Laboratories, Palo Alto, CA). The isolated RNA was considered intact and of good quality if distinct $28 \mathrm{~S}$ and $18 \mathrm{~S}$ bands were seen.

Synthesis of cDNA. For reverse transcription, $2 \mu \mathrm{g}$ of RNA and $\operatorname{pd}(\mathrm{N}) 650$ $\mu \mathrm{M}$ (Pharmacia-Upjohn, Uppsala, Sweden) were used together with dNTPs,
$10 \mu \mathrm{M}$ each (Pharmacia-Upjohn), RNase inhibitor 40U/mL (Promega, Madison, WI, USA), Superscript 200U/mL (RNase H-Reverse Transcriptase, Invitrogen, Carlsbad, CA) First Stand Buffer (Invitrogen) and distilled water DNAse and RNAse free (GIBCO, Invitrogen) were added to a total volume of $30 \mathrm{~mL}$. The mixture was incubated at $42^{\circ} \mathrm{C}$ for one hour with termination at $70^{\circ} \mathrm{C}$ for $10 \mathrm{~min}$.

RT-PCR (Riverse Transcriptase-Polymerase Chain Reaction). Real time PCR was performed for the quantification of gene expression using a LightCycler rapid thermal system (Roche Diagnostic Ltd, Lewes, UK) according to the manufacturer's instructions. A LightCycler FastStart DNA Master SYBR Green I kit (Roche Diagnostics Scandinavia AB, Bromma, Sweden) was used together with LightCycler-Primer Set Kits (Search-LC, GmbH Heidelberg, Germany) for the housekeeping gene glyceraldehyde-phosphate-dehydrogenase (GAPDH), IL-10, IL-8, TNF- $\alpha$, TGF- $\beta$, IL-6, IL- 4 , IL- $1 \beta$, IL-12 and INF-g. Reactions were performed in a $20 \mu \mathrm{L}$ volume with $10 \mu \mathrm{L}$ master mix (containing $2 \mu \mathrm{L}$ of SybrGreen mix, $6 \mu \mathrm{L}$ of specific primers for each cytokine and $2 \mu \mathrm{L}$ of sterile water) and $10 \mu \mathrm{L}$ of cDNA diluted five times for IL-10, IL-8 and TNF- $\alpha$, and 20 times for other cytokines. The run was programmed according to the LightCycler-Primer Set Kits instructions. The first step was $10 \mathrm{~min}$ denaturation at $95^{\circ} \mathrm{C}$, followed by 35 cycles for GAPDH, 45 cycles for the remaining cytokines, $95^{\circ} \mathrm{C}$ denaturation for $10 \mathrm{~s}, 68^{\circ} \mathrm{C}-58^{\circ} \mathrm{C}$ annealing for $10 \mathrm{~s}$ decreasing $0.5^{\circ} \mathrm{C} /$ cycle and finally $72^{\circ} \mathrm{C}$ extension for $16 \mathrm{~s}$. The PCR products were subjected to melting curve-analyses starting with $58^{\circ} \mathrm{C}$ rising to $95^{\circ} \mathrm{C}$, increasing $0.1^{\circ} \mathrm{C} / \mathrm{s}$ to confirm the product specificity.

The results were expressed as a ratio between the concentration of the housekeeping gene GAPDH and the relevant cytokine in each sample.

Cytokine gene polymorphisms. Five $\mathrm{mL}$ of heparinized blood was collected from each mother/child pair. The blood samples were frozen at $-20^{\circ} \mathrm{C}$, sent to Sweden on dry ice and kept frozen until handled.

PCR amplification of $1 \mathrm{~mL}$ (30 ng) DNA was performed for +915TGFB1, intron 2 IL1RN, -1087IL10, -308TNFA, -174IL6, +36TNFR1, 150V IL4RA and -159 CD14. For this GeneAmp PCR system 9600, Perkin Elmer (Norwalk, CT, USA) and GeneAmp PCR system 2700 (Applied Biosystems, Foster City, CA, USA) were used.

intron 2 IL1RN amplification with primers, upper 5'CTCAGCAACACTCCTAT3' and lower 5'CTAAAATCCCGAGGTCAGAA3', was done with $2 \mu \mathrm{M} \mathrm{MgCl}, 0.2 \mu \mathrm{M}$ of each dNTP (Amersham Biosciences, Piscataway NJ, USA), $0.4 \mu \mathrm{M}$ of each primer (TIB MOLBIOL Syntheselabor, Berlin, Germany), 1.25 U AmpliTaq Gold DNA polymerase (Roche, Applied Biosystems, New Jersey, USA), PCR buffer II and sterile water, total volume of $25 \mathrm{~mL}$. PCR program was: $12 \mathrm{~min}$ at $94^{\circ} \mathrm{C}, 27$ cycles of $94^{\circ} \mathrm{C}$ for $30 \mathrm{~s}$, $60^{\circ} \mathrm{C}$ for $1 \mathrm{~min}, 72^{\circ} \mathrm{C}$ for $2 \mathrm{~min}$ and $72^{\circ} \mathrm{C}$ for $5 \mathrm{~min}$. PCR for $-1087 \mathrm{IL} 10$, upper primer 5'AAGGCAACACTACTAAGGCTTCCTT3' and lower primer 5'TAAATATCCTCAAAGTTCC 3' was carried out as for intron 2 IL1RN except that $4 \mu \mathrm{M} \mathrm{MgCl}_{2}$ was used and the PCR program was: $24 \min 94^{\circ} \mathrm{C}$ and 37 cycles. PCR for +36TNFR1, upper primer 5'CTGACCGGAGGGACAGAATTCAGAA3' and lower primer 5'CTGCCCTGAGCCCAAATGGTGGAGT3', was the same as for intron 2 IL1RN, but for PCR program: 24 min $94^{\circ} \mathrm{C}, 40$ cycles of $94^{\circ} \mathrm{C} 1 \mathrm{~min}, 70^{\circ} \mathrm{C} 1 \mathrm{~min}$ and $72^{\circ} \mathrm{C}$ for $5 \mathrm{~min}$. PCR for -308TNFA, upper primer 5'ACACAAGCATCAAGGATACCCCTCAC3' and lower primer 5'CTCCCCCTCAACGGACTCAGC3', was as for intron 2 IL1RN, but for PCR program: $24 \mathrm{~min} 94^{\circ} \mathrm{C}$ and 30 cycles. - 159CD14, upper primer 5'AGGCTTAGGCTCCCGAGTCAA3' and lower primer 5'TCCTACACAGCGGCACC $3^{\prime}$, was performed the same way as intron 2 IL1RN, the difference was in the PCR program: $24 \min 94^{\circ} \mathrm{C}, 32$ cycles of $94^{\circ} \mathrm{C} 30 \mathrm{~s}$, $60^{\circ} \mathrm{C} 30 \mathrm{~s}, 72^{\circ} \mathrm{C} 60 \mathrm{~s}$ and $72^{\circ} \mathrm{C}$ for $5 \mathrm{~min}$. PCR for $150 \mathrm{~V}$ IL4RA, upper primer 5'TGGCAAGCAAGAGAGGCAACCCT3' and lower primer 5'CTCACCATGCTTCGCTGGGCTTGA3', was done in the same way as intron 2 IL1RN, PCR program: 24 min $94^{\circ} \mathrm{C}, 30$ cycles of $94^{\circ} \mathrm{C} 30 \mathrm{~s}, 60^{\circ} \mathrm{C} 30 \mathrm{~s}, 72^{\circ} \mathrm{C}$ $60 \mathrm{~s}$ and $72^{\circ} \mathrm{C}$ for $5 \mathrm{~min}$. $-174 \mathrm{IL} 6$, upper primer $5^{\prime}$ TTGTCAAGACATGCCAAGTGCT3' and lower primer 5'GCCTCAGAGACATCTCCAGTCC 3 ', was performed as intron 2 IL1RN, the difference in PCR program was; 24 min $94^{\circ} \mathrm{C}, 35$ cycles of $94^{\circ} \mathrm{C} 30 \mathrm{~s}, 60^{\circ} \mathrm{C} 30 \mathrm{~s}, 72^{\circ} \mathrm{C} 60 \mathrm{~s}$ and $72^{\circ} \mathrm{C}$ for $5 \mathrm{~min}$. +915TGFB1, upper primer $5^{\prime}$ GCCTCCCGATGCCGCCCTCCGGGCTGCGGCGGCGGC3' and lower primer 5'GTAGTCGGCCTCAGGCTCGGGCTCC3', amplification was done with $3 \mu \mathrm{M} \mathrm{MgCl}_{2}, 0.2 \mu \mathrm{M}$ of each dNTP (Amersham Biosciences), $0.4 \mu \mathrm{M}$ of each primer (TIB MOLBIOL), $2.5 \mathrm{U}$ AmpliTaq Gold DNA polymerase (Roche), $2.5 \mu \mathrm{L} /$ prove of DMSO (KEBO, E. Merck, Darmstadt), PCR buffer II and sterile water, in total volume of $25 \mathrm{~mL}$. PCR program for the reaction was: $12 \min 94^{\circ} \mathrm{C}, 40$ cycles of $94^{\circ} \mathrm{C} 30 \mathrm{~s}, 72^{\circ} \mathrm{C} 1 \mathrm{~min}$ and $72^{\circ} \mathrm{C}$ for $5 \mathrm{~min}$.

A specific restriction enzyme for each cytokine (New England BioLabs Inc, Bevery, MA, USA) cleaved the PCR-products at the designated locations and the resulting fragments (representing specific alleles) were resolved on $4-20 \%$ polyacrylamide gels (Invitrogen) in the presence of the molecular size marker $\times 174 /$ Hae III-digested DNA (Invitrogen). The genotypes for +915 TGFB1 were detected by cleavage with Bg1 I, of -1087IL10 by EcoN 
I, $-308 \mathrm{TNFA}$ and 150V IL4RA by BsmF I, $-174 \mathrm{IL} 6$ by NlaIII, +36TNFR1 by MspA1 I, and $-159 \mathrm{CD} 14$ by HpyCH4 III. Gels were developed according to the manufacturer, with the DNA Silver Staining Kit (Amersham Biosciences AB, Uppsala, Sweden).

Determination of cytokines in serum by Luminex and ELISA. Serum was collected in Pakistan from each mother/child pair, frozen at $-20^{\circ} \mathrm{C}$ and sent to Sweden on dry ice where kept frozen until handled.

The levels of IL-1 $\beta$, IL-6, IL-8, IL-10, IL-12, TNF- $\alpha$ and TGF- $\beta$ in serum were measured with Bio-Plex human cytokine assays (Bio-Rad Laboratories $\mathrm{AB}$, Sundbyberg, Sweden) according to the manufacturer. Data were analysed with the Bio-Plex Manager ${ }^{\mathrm{TM}}$ software version 2.0 (Bio-Red) with 4LP and 5LP curve fits. The samples that gave very high values in Luminex were analyzed with the ELISA based on specific monoclonal catching antibodies used for coating (17), the certified method used at the Clinical Immunologic Laboratory at the Sahlgrenska University Hospital, Göteborg, Sweden.

Statistical analyses. Expression of the mRNA and protein levels for each cytokine in different groups were analyzed using Mann-Whitney test. A significant difference was at $p<0.05$. Genotype frequencies in different groups were compared using chi-square test. All calculations were done using StatView program, version 4.5. (SAS Institute Inc., USA).

\section{RESULTS}

The parameters characterizing the mother/child pairs divided in four groups, as well as the number of pairs in each group included in our study, are summarized in Table 1. Sixty two percent of the IUGR newborns were delivered by Caesarean section. The placental weight (mean) was significantly lower $(p<0.0001)$ in the IUGR group than in the non-IUGR group. Almost half, 11/24, of the preterm IUGR newborns died after delivery. The mean maternal weight was significantly lower $(p<0.02)$ among the IUGR mothers whereas the height was not different from the non-IUGR group. Consanguinity was slightly more common, but not significantly, in the IUGR group $(29 / 45,64 \%)$ compared with the non-IUGR $(32 / 55,58 \%)$.

Cytokine gene expression. There was a significant decrease of mRNA expression in the decidua of the IUGR placentas for IL-10 $(p<0.0001)$ and IL-12 $(p<0.008)$ and in the trophoblasts for IL-10 $(p<0.03)$ compared with the non-

Table 1. The variables defining the study population

\begin{tabular}{|c|c|c|c|c|}
\hline & \multicolumn{2}{|c|}{ Non-IUGR } & \multicolumn{2}{|c|}{ IUGR } \\
\hline & Full-term & Pre-term & Full-term & Pre-term \\
\hline Number & 30 & 25 & 21 & 24 \\
\hline \multicolumn{5}{|l|}{ Mode of delivery } \\
\hline Vaginal & $15(50 \%)$ & $19(76 \%)$ & $8(38 \%)$ & $9(38 \%)$ \\
\hline Caesarean-section & $15(50 \%)$ & $6(24 \%)$ & $13(62 \%)$ & $15(62 \%)$ \\
\hline $\begin{array}{l}\text { Placental weight in } g \\
\text { (mean) }\end{array}$ & 583 & 447 & 431 & 308 \\
\hline \multicolumn{5}{|l|}{ Newborns: } \\
\hline Weight in kg (mean) & 3.0 & 2.4 & 2.02 & 1.5 \\
\hline Hight in cm (mean) & 48.4 & 44 & 45.1 & 38.9 \\
\hline Males & $15(50 \%)$ & $17(68 \%)$ & $16(76 \%)$ & $8(33 \%)$ \\
\hline Females & $15(50 \%)$ & $8(32 \%)$ & $5(24 \%)$ & $16(67 \%)$ \\
\hline \multicolumn{5}{|l|}{ Outcome: } \\
\hline Death & $1(3 \%)$ & $2(8 \%)$ & $3(14 \%)$ & $11(46 \%)$ \\
\hline Stillbirth & 0 & 0 & $1(5 \%)$ & $2(8 \%)$ \\
\hline \multicolumn{5}{|l|}{ Mothers: } \\
\hline Weight in kg (mean) & 74.1 & 65.7 & 64.8 & 64.2 \\
\hline Height in $\mathrm{cm}$ (mean) & 152 & 155.4 & 155.4 & 154.2 \\
\hline \multicolumn{5}{|l|}{ Consanguinity: } \\
\hline Related & $16(53 \%)$ & $16(64 \%)$ & $13(62 \%)$ & $16(67 \%)$ \\
\hline Not related & $14(47 \%)$ & $9(36 \%)$ & $8(38 \%)$ & $8(33 \%)$ \\
\hline
\end{tabular}

IUGR group (Fig. $1 A-C$ ). There was a significant increase of mRNA expression for TGF- $\beta$ both in the decidua $(p<0.009)$ and the trophoblasts $(p<0.009)$ of the IUGR placentas compared with the non-IUGR group (Fig. $2 A, B$ ).

In the placentas of the preterm group, significantly reduced expression of the TGF- $\beta$ mRNA was found in the trophoblasts $(p<0.03)$ compared with the full-term group. TGF- $\beta$ mRNA was diminished in both the decidua and the trophoblasts of the preterm IUGR group compared with the full-term IUGR group ( $p<0.0005$ and $p<0.005$ respectively).

In the trophoblasts the IL-12 mRNA expression was significantly reduced in the preterm non-IUGR compared with the full-term non-IUGR group $(p<0.04)$. There were no significant differences in the mRNA expression of IL- 4 , IFN- $\gamma$, IL- 8, IL- $1 \beta$, IL- 6 and TNF- $\alpha$ between any of the groups.

Gene polymorphisms. There were no significant differences between the intron 2 IL1RN, +915TGFB1, +36TNFR1, -308TNFA, -1087IL10, 150V IL4RA, -159 CD14 and -174IL6 genotypes in any of the groups. The population was in this respect homogenous.

The distribution of the genotype frequencies was compared in the Pakistani women and Swedish Caucasian women. There were significant differences in the distribution of -1087 IL10 $(p<0.0008),-308$ TNFA $(p<0.04)$ and -159 CD14 $(p<$ $0.04)$ genotype frequencies between the two populations.

Cytokine serum levels. Serum analyses showed that the levels of the IL- $1 \beta$ were significantly down-regulated in the IUGR mothers compared with the mothers of the non-IUGR group $(p<0.008)$. TGF- $\beta$ was significantly down-regulated in the preterm group of mothers compared with the full-term group $(p<0.005)$.

In the serum of the IUGR infants the TGF- $\beta$ levels were down-regulated compared with the infants of the non-IUGR group $(p<0.05)$ and in the full-term infants the IL-10 levels were reduced compared with the pre-term infants $(p<0.05)$.

\section{DISCUSSION}

Considering the fact that IUGR is a major risk factor for newborns in poor countries (3) it is important to search for the mechanisms behind this condition in the hope of finding methods for its prevention and/or treatment.

In the present study from Pakistan a main finding is that the IL-10 mRNA expression is down-regulated in both decidua and trophoblasts of the IUGR placentas. The reduction of IL-10 in the decidua agrees with the results of our previous study in a Swedish population (14). The socio-economical and health situation is very different for Swedish and Pakistani mothers, with many more risk factors for IUGR in Pakistan. Still a similar reduction in the IL-10 mRNA expression was found in the Pakistani IUGR placentas as in the Swedish. IL-10 is a major anti-inflammatory and down-regulatory cytokine. It is not only produced by lymphocytes in the placenta but also by the placenta itself (18). The role of IL-10 during pregnancy has been and still is discussed. Two different studies in IL-10 knock-out (KO) mice have reported that IL-10 is not needed for a successful pregnancy $(19,20)$. However, they disregarded the fact that there are several functional 

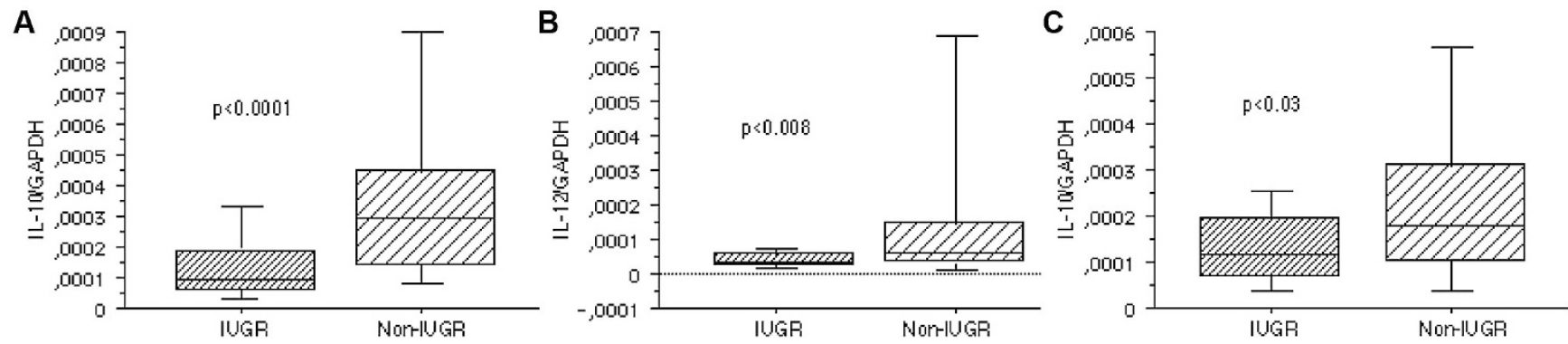

Figure 1. mRNA expression of IL-10 and IL-12 in the decidua and trophoblasts of IUGR and non-IUGR pregnancies. (A) IL-10 mRNA in the decidua of the IUGR was significantly decreased compared with the decidua of the non-IUGR placentas $(p<0.0001)$. (B) IL-12 mRNA in the decidua of the IUGR was significantly decreased compared with the decidua of the non-IUGR placentas $(p<0.008)$. (C) IL-10 mRNA in the trophoblast of the IUGR was significantly decreased compared with the trophoblast of the non-IUGR placentas $(p<0.03)$. The results in this figure are expressed as a ratio between the concentration of the housekeeping gene GAPDH and the relevant cytokine in each sample. IUGR $n=45$; non-IUGR $n=55$.

analogues to IL-10, like IL-19, IL-20, IL-22, IL-24 and IL-26 which may have taken over (21), although it is not clear if all these analogues can cover all aspects of the functions of IL-10. In addition we do not know if some of these cytokines may also be reduced in cases of IUGR. Another study in Th2 cytokine $\mathrm{KO}$ mice (even quadruple cytokine KOs i.e., IL-4, IL-5, IL-9 and IL-13 showed that these cytokines were not essential for fetal survival (22).

We observed an up-regulation of the TGF- $\beta$ in the IUGR compared with the control group in both the decidua and the trophoblasts. TGF- $\beta$ is produced by mononuclear phagocytes, activated T-cells and other cells. Its main action is to stop the proliferation and differentiation of T-cells, to inhibit the activation of macrophages and to reduce the effects of proinflammatory cytokines (23). TGF- $\beta$ controls the growth of trophoblasts and is present throughout pregnancy. One study has found that TGF- $\beta$ was higher in the IUGR in the first trimester of the pregnancy compared with the last two. However, the concentration of TGF- $\beta$ remained high in the IUGR pregnancies (24). In vitro studies have described possible mechanisms by which TGF- $\beta$ may regulate trophoblast invasion. Thus, trophoblast invasive capacity may be inhibited by treatment with TGF- $\beta$ probably by the inhibition of matrix metalloproteinase-9 (MMP-9) and plasmin and/or by overexpression of the TGF- $\beta$ trans-membrane-binding protein endoglin (25). The high levels of TGF- $\beta$ mRNA in the decidua and trophoblasts in Pakistani material seemed surprising since this cytokine is considered immunosuppressive. A recent study has shown, however, that TGF- $\beta$ is responsible for the CD103 expressing CD8 + T-cells causing graft vs. host reaction after bone marrow transplantation. It may be that the increased TGF- $\beta$ in the Pakistani IUGR pregnancies could be damaging and even linked to the fact that IUGR is so much more common in Pakistan than in Sweden (26).

We also observed a down-regulation of the IL-12 mRNA expression in the decidua of the IUGR placentas. IL-12 is a pro-inflammatory cytokine. It is needed for differentiation of T-cells to Th1 cells, but its role in pregnancy is not known. Studies in patients suffering from spontaneous abortions have shown down-regulation of IL-12 in peripheral leukocytes and monocytes. The same was true for preeclamptic patients (27).

IUGR is a complex problem with a number of risk factors. In this study we have excluded mothers showing external risk factors for IUGR like malnutrition, infections and twin pregnancies, and concentrated on placenta-related IUGR. However, one risk factor in this study is consanguinity, which was somewhat more prevalent in the IUGR group than in the non-IUGR group (64\% and 58\% respectively) but not significantly different. In the region of this study consanguinity is present in close to $50 \%$ of pregnancies (28), but is absent in the Swedish population. A negative influence of inbreeding on birth size has been shown (4).

Infants born with IUGR, or those born SGA may catch up in growth during the first few years of age if the nutritional and hygienic situation is appropriate (29). However, they remain more susceptible to infections. The reasons for that are not well understood, but recently we found that Pakistani adults who had had low birth weight showed significantly reduced antibody responses to a Salmonella typhi VI polysaccharide vaccine (30). It might be that a secondary immunodeficiency for encapsulated bacteria like pneumococci, meningococci and Haemophilus influenzae type b, remaining after an IUGR delivery, may result in more frequent and severe infections. The information in cases of IUGR about the functional capacity of the immune system and its signals including the cytokines, is sparse. We did not find that the polymorphisms in the tested cytokine genes of intron 2 IL1RN, +915TGFB1, +36TNFR1, -308TNFA, -1087IL10, 150V IL4RA, -159 CD14 and -174 IL6 could be linked to IUGR. Thus no risk group could be defined in this way.

It would be important to find more evidence for whether or not a deficiency of IL-10 in the decidua could be a pathogenic mechanism in IUGR, because then it might be possible to find a strategy for treatment. Recently it was shown in an animal model that without regulatory T-cells producing IL-10, pregnancies ended in abortions $(31,32)$. That model might be used to further analyze the possibility that the amount of the IL-10 produced by maternal regulatory T-cells in the placenta may be crucial for the normal growth and development of the fetus.

In conclusion, even though the genetic, social and nutritional circumstances may be quite different for pregnant women in Pakistan and Sweden, IUGR pregnancies in both countries have one feature in common; they are associated with a low expression of the IL-10 in the placenta, primarily in the decidua. This might indicate a common pathway in the pathogenesis of IUGR. 

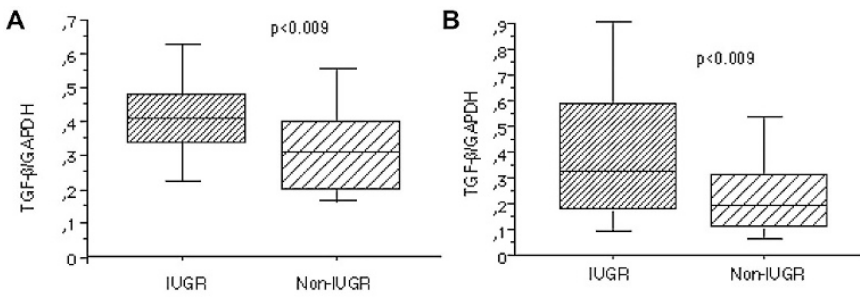

Figure 2. mRNA expression of TGF- $\beta$ in the placentas of the IUGR and non-IUGR groups. ( $A$ ) There was a significant increase in the expression of the TGF- $\beta$ mRNA in the decidua of the IUGR compared with the non-IUGR placentas $(p<0.009)$. (B) There was a significant increase of the TGF- $\beta$ mRNA in the trophoblasts of the IUGR compared with the non-IUGR placentas $(p<0.009)$. The results in this figure are expressed as a ratio between the concentration of the housekeeping gene GAPDH and the relevant cytokine in each sample. IUGR $n=45$; non-IUGR $n=55$.

Acknowledgements. Many thanks to the hard working hospital staff in Pakistan without which this study would not have been possible.

\section{REFERENCES}

1. Clausson B, Cnattingius S, Axelsson O 1999 Outcomes of post-term births: the role of fetal growth restriction and malformation. Obstet Gynecol 94:758-762

2. Parkinson CE, Scrivener R, Graves L, Bunton J, Harvey D 1986 Behavioural differences of school-age children who were small-for-dates babies. Dev Med Child Neurol 28:498-505

3. Jalil F, Lindblad BS, Hanson LÅ, Khan SR, Yaqoob M, Karlberg J 1993 Early child health in Lahore, Pakistan: IX. Perinatal events. Acta Paediatr Suppl 390:95-107

4. Fikree FF, Berendes HW 1994 Risk factors for term intrauterine growth retardation: a community-based study in Karachi. Bull Worth Health Organ 72:581-587

5. Wennergren M, Karlsson K, Olsson TA 1982 A scoring system for antenatal identification of fetal growth retardation. Br J Obstet Gynaecol 89:520-524

6. Khong TY, De Wolf F, Robertson WB, Brosens I 1986 Inadequate maternal vascular response to placentation in pregnancies complicated by pre-eclampsia and by small-for-gestational age infants. Br J Obstet Gynaecol 93:1049-1059

7. Pardi G, Marconi AM, Cetin I 2002 Placental-fetal interrelationship in IUGR fetuses-a review. Placenta 23:136-141

8. Yui J, Garcia-Lloret M, Wegmann TG, Guilbert LJ 1994 Cytotoxicity of tumor necrosis factor-alpha and gamma-interferon against primary human placental trophoblasts. Placenta 15:819-835

9. Armstrong DT, Chaouat G 1989 Effects of lymphokines and immune complexes on murine placental cell growth in vitro. Biol Reprod 40:466-474

10. Athanassakis I, Bleackley RC, Paetkau V, Guilbert L, Barr PJ, Wegmann TG 1987 The immunostimulatory effects of T-cells and $\mathrm{T}$ cell lymphokines on murine fetally derived placental cells. J Immunol 138:37-44

11. Chaouat G, Menu E, Clark DA, Minkowski M, Dy M, Wegmann TG 1990 Control of fetal survival in CBAxDBA/2 mice by lymphokine therapy. J Reprod Fertil 89:447-458

12. Holcberg G, Huleihel M, Sapir O, Katz M, Tsadkin M, Furman B, Mazor M, Myatt L 2001 Increased production of tumor necrosis Factor-a, TNF- $\alpha$ by IUGR human placentae. Eur J Obstet Gynecol Reprod Biol 94:69-72
13. Ogasawara MS, Aoki K, Aoyama T, Katano K, Iinuma Y, Ozaki Y, Suzumori K 2000 Elevation of transforming growth factor-b1 is associated with recurrent miscarriage. J Clin Immunol 20:453-457

14. Hahn-Zoric M, Hagberg H, Kjellmer I, Ellis J, Wennergren M, Hanson LÅ 2002 Aberrations in placental cytokine mRNA related to intrauterine growth retardation. Pediatr Res 51:201-206

15. Laurin J, Lingman G, Marsal K, Persson PH 1987 Fetal blood flow in pregnancies complicated by intrauterine growth retardation. Obstet Gynecol 69:895-902

16. Marsal K, Persson PH, Larsen T, Lilja H, Selbing A, Sultan B 1996 Intrauterine growth curves based on ultrasonically estimated fetal weights. Acta Peadiatr 85:843848

17. Wuyts A, Proost P, Van Damme J 1998 Interleukin-8 and other CXS Chemokines. In: Thomson AW (ed) The Cytokine Handbook, $3^{\text {rd }}$ ed. Academic Press, San Diego, pp 271-311

18. Cadet P, Rady PL, Tyring SK, Yandell RB, Hughes TK 1995 Interleukin-10 messenger ribonucleic acid in human placenta: implications of a role for interleukin-10 in fetal allograft protection. Am J Obstet Gynecol 173:25-29

19. Svensson L, Arvola M, Sällström Holmdahl R, Mattsson R 2001 The Th2 cytokines IL-4 and IL-10 are not crucial for the completion of allogeneic pregnancy in mice. J Reprod Immunol 51:3-7

20. White CA, Johansson M, Roberts CT, Ramsay AJ, Robertson SA 2004 Effect of interleukin-10 null mutation on maternal immune response and reproductive outcome in mice. Biol Reprod 70:123-131

21. Kotenko SV 2002 The family of IL-10-related cytokines and their receptors: related, but to what extent? Cytokine Growth Factor Rev 13:223-240

22. Fallon PG, Jolin HE, Smith P, Emson CL, Townsend MJ, Fallon R, Smith P, McKenzie AN 2002 IL-4 induces characteristic Th2 responses even in the combined absence of IL-5, IL-9 and IL-13. Immunity 17:7-17

23. Abbas AK, Lichtman AH, Pober JS 2000 Cellular and Molecular Immunology. 4th ed. Saunders, Philadelphia pp 497

24. Hernandez-Valencia M, Zarate A, Ochoa R, Fonseca ME, Amato D, De Jesus Ortiz, M 2001 Insulin-like growth factor I, epidermal growth factor and transforming growth factor beta expression and their association with intrauterine fetal growth retardation, such as development during human pregnancy. Diabetes Obes Metab 3:457-462

25. Dimitriadis E, White CA, Jones RI, Salamonsen LA 2005 Cytokine, chemokines and growth factors in endometrium related to implantation. Hum Reprod Update 11:613630

26. El-Asady R, Yuan R, Liu K, Wang D, Gress RE, Lucas PJ, Drachenberg CB, Hadley GA 2005 TGF- $\beta$-dependent CD103 expression by CD8 + T-cells promotes selective destruction of the host intestinal epithelium during graft-versus-host disease. J Exp Med 201:1647-1657

27. Zenclussen AC, Fest S, Busse P, Joachim R, Klapp BF, Arck PC 2002 Questioning the Th1/Th2 paradigm in reproduction: peripheral levels of IL-12 are downregulated in miscarriage patients. Am J Reprod Immunol 48:245-251

28. Shami SA, Grant JC, Bittles AH 1994 Consanguineous marriage within social/ occupational class bounders in Pakistan. J Biosoc Sci 26:91-96

29. Albertsson-Wikland K, Wennergren G, Wennergren M, Vilbergsson G, Rosberg S 1993 Longitudinal follow-up of growth in children born small for gestational age. Acta Paediatr 82:438-443

30. Moore SE, Jalil F, Ashraf R, Szu SC, Prentice AM, Hanson LÅ 2004 Birth weight predicts response to vaccination in adults born in an urban slum in Lahore, Pakistan. Am J Clin Nutr 80:453-459

31. Jutel M, Akdis M, Budak F, Aebischer-Casaulta C, Wrzyszcz M, Blaser K, Akdis CA 2003 IL-10 and TGF- $\beta$ cooperate in the regulatory T cell response to mucosal allergens in normal immunity and specific immunotherapy. Eur J Immunol 33:12051214

32. Sasaki Y, Sakai M, Miyazaki S, Higuma S, Shiozaki A, Saito S 2004 Decidual and peripheral blood $\mathrm{CD} 4{ }^{+} \mathrm{CD} 25^{+}$regulatory T-cells in early pregnancy subjects and spontaneous abortion cases. Mol Hum Reprod 10:347-353 